\title{
Artistic participatory practices as a vehicle for togetherness
}

\author{
Rosanne van Klaveren \\ rosanne@foodrelated.org \\ MAD-faculty, C-mine 5, 3600 Genk, Belgium
}

\begin{abstract}
In all its functions and possibilities art has the option to be more embedded in societies, in dealing with social and political issues, than ever before. For example, community art became a common art practice during the previous decennia: artists temporarily work within particular communities to create art together with participating citizens. Also in design and design research we see a growing use of participatory practices in which the knowledge, experience and creativity of community members are valued beyond inspiration. But how can artists deal with the notion of togetherness when they are outsiders to the communities they work with? How can they overcome the colonial us-and-them dichotomy that is still a common handicap in community art and in other forms of artistic participatory practice? This conference paper discusses which conditions can help in the creation of a temporarily 'we' during participatory practices. Anthropological approaches and design methods are brought together with self-discovered insights of the artist-writer, picked up during many years of participatory practice and her artistic $\mathrm{PhD}$ research involving Arctic indigenous communities.
\end{abstract}

KEYWORDS: participatory practices, community art, togetherness

\section{Introduction}

The way in which artistic participatory practices can create a temporary feeling of togetherness between an artist and a community is explored in this conference paper. With human relations and social context as their point of departure, community artists handle a varied range of skills, methods and tools to create space or to moderate circumstances for shared activities. These kind of participatory practices are usually not held in the white cube settings of Art with a distant capital A, wherefore community art has built a bridge between art and society, away from aristocratic tendencies. Artistic participatory practices, which are not exclusively initiated by community artists or artists in general, can establish connections between people and strengthen or create communities. Such relations need to be worked on, 
especially when the artist is an outsider to the community. This conference paper gives insights in some aspects of collaborative relationships and some possibilities to overcome distance, which can be beneficial to artists working with communities or to other people who design, direct or moderate participatory practices. The character of these practices, meaning what participants actually do or make, can differ so greatly that it is deliberately left out of this discussion.

\section{TOGETHERNESS}

As a response to my experiences in community art and in contact with indigenous communities, I am investigating how it is possible to create a temporary feeling of togetherness among the artist/researcher and the community s/he is working with. Although a similar feeling is often aimed for among the community members, as is for example one of the common goals in community work, this paper explicitly focuses on the declining of distance between the community members and the artist/researcher as outsider to the community. In my opinion this distance is not beneficial to the collaboration, or to the end result. It is similar to the us-and-them dichotomy that contemporary anthropology tries to avoid. Anthropologists have studied peoples that were foreign to them for many decades, underlining the differences by calling them 'natives'. According to Arjun Appadurai (1988), this was a colonial act that strengthened not only the dichotomy, but the suppressing powers as well. Although dichotomies can be handy during the process of identification, they often lead to oversimplification and exclude others too easily. Such dichotomies therefore need to be avoided. Paul Stoller acknowledged the differences but positioned the anthropologist in the 'between': '... between 'being there,' as the late Clifford Geert?. put it and 'being-here,' between two or more languages, between two or more cultural traditions, between two or more apprehensions of reality" (Stoller, 2009). This 'between' is a very powerful and creative space for anthropologists, where strength can be drawn from both sides and where a creative air of indeterminacy can be breathed (Stoller, 2009). A similar 'between' can be a first step in avoiding the us-andthem dichotomy in community art, or a first step towards a temporary feeling of togetherness.

During the practice of participant observation, creative participation, participatory action research (PAR) or other present day social science methodologies that include participation with communities, it is never the aim to become part of the community 'forever' or by all means. Just as community members shouldn't become re-searchers in order to create togetherness. The role and purpose of the researcher is and stays different from those of the community members, and so do the other differences in identity and perspectives. I believe though, that during the act of participation, artistic and creative practices can bring people more together, temporary. The act of expression can build a metaphorical bridge between them, where researchers and community members can meet each other in the middle, in the between. Differences in background, habits and world view can be left behind during the shared activity. A temporary feeling of togetherness, also to be described as a feeling of solidarity or connectedness, can occur in this shared moment, which will diminish when people end the activity and go back to the 'us' that distances 'them'. Though, people are always allowed to be different and they better stay themselves, whatever 'us' or 'them' they belong to. After all, the inclusion of different experiences is always one of the added values of participatory practices. 


\section{THE BURDEN OF A BIG EGO}

It interests me how artists deal with the notion of us-and-them, and how they position themselves in society. In my opinion artists sometimes have the tendency to develop a big ego, probably in response to unorthodox teaching methods at art schools or to build resistance against fatal criticism elsewhere. Those egos fit well in the upmarket art world, where sophisticated art is being made for the happy few, but in community art it is one of the heaviest burdens. I will illustrate my thoughts with one of the roots of the merge between art and society: Gustave Courbet.

The French artist Gustave Courbet (1819-1877) inspired many people with his statements and realistic paintings that led the Realist movement in 19th century French painting. He was one of the first artists to address social issues in his work, which he named 'living art'. His realistic focus on everyday life was far ahead of its time and exceeded the canvas of his paintings. As a man with great sympathy for the gross, Courbet wanted to eliminate all street names in Paris that recalled imperial victories, replacing them by the names of benefactors of humanity (Doesschate Chu, 1992). These social issues as a living art, even his anarchistic longing for freedom, inspired me as well. Still, I find one of his paintings a bit troublesome. I am referring to 'The Meeting' (La Rencontre) from 1854 which documents his arrival at Montpellier where he is greeted by his patron Bruvas, accompanied by a servant and a dog.

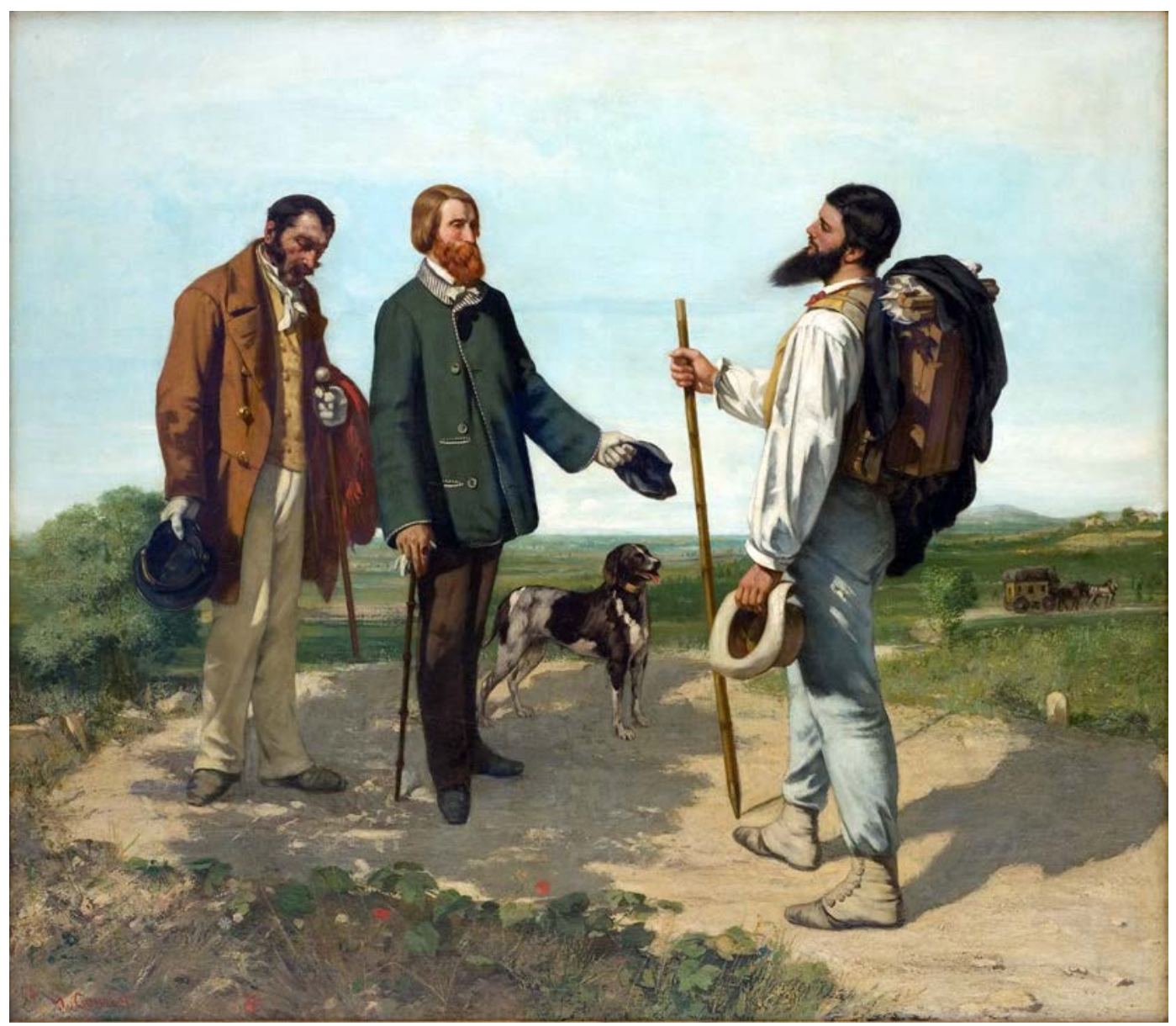

Image 1. G. Courbet, 1854, La Rencontre or Good Morning Mr. Courbet (Musee Fabre, Montpellier) 
For an artist who is so concerned with social issues, it shows off how in this painting his ego absorbs all attention. Courbet painted himself obviously as more important than anything else presented in the scenery. The whole gesture of this painted artist emanates superiority. The two men are there to show their respect towards the great artist arriving in their humble community with his powerful toolbox. Only the dog is showing no submissive response to the dominant character, unless his scale is purposely reduced.

I am not the only one who found the representation of the artist offending. The writer and journalist Edmond About criticized that Courbet "... carefully emphasized all the perfections of this own person. Even his shadow is graceful and full of vigour: it displays a pair of calves such as are seldom met with in the world of shades. .... Neither master nor valet casts a shadow on the ground; there is no shadow except for M. Courbet; he alone can stop the rays of the sun" (Mack, 1989). The painting was soon nicknamed 'Bonjour, Monsieur Courbet!' and even 'Fortune Bowing before Genius' when it was shown at the Exhibition Universelle. Courbet's paintings instigated scandals before when he refused to represent reality more beautiful than it was. But this time he upgraded the representation of himself, unless he truly valuated his appearance as such an honourable man. In either way, it was not appreciated. But we should of course be careful when judging work from another era and especially when filling in the reason why Courbet presented himself like this. The position of artists was different in his time, wherefore we can also assume that his painted gestures where an act of self-empowerment. As an artist he wanted to be autonomous and therefore probably refused to bow for his bourgeois benefactors. We should give Courbet many credits and can even be grateful to the size of his ego, because without his often described arrogance and self-importance he was most probably not able to introduce Realism that well.

For me though, 'The Meeting' will always be a reminder of the big ego artists can sometimes have. When entering a community in order to establish participatory practices, we must be aware of the fact that we are the guests that rely completely upon the hospitality and goodwill of the community members. Perhaps we can take example by the humble gestures of the patron and his servant; better to show a bit too much respect than a bit too little. If you want to practice community art knowing your ego might interfere, it is a good exercise to greet everything around you with respect. Don't stop with people: also your attitude towards objects, situations, stories and experiences is influenced by your ego and will therefore have an underestimated impact on the quality of participatory practices.

I tried this myself when I visited Greenland for the first time in 2001. While entering the town Ilulíssat after a two-day hiking trip I asked my companion to make a picture of my greetings. Though it is partly my heavy backpack filled with basic necessaries that makes me bow while my sticks support a different kind of balance than Courbet's, my gesture addresses friendliness. The dogs show two possible responses you may expect in return: interest and indifference. No matter how friendly you are or become, disinterest is always encountered. Practice your gestures as often as needed to overcome the first handicap for creating togetherness: an ego too big to give room to others. As happened to Courbet, this will not be appreciated. 


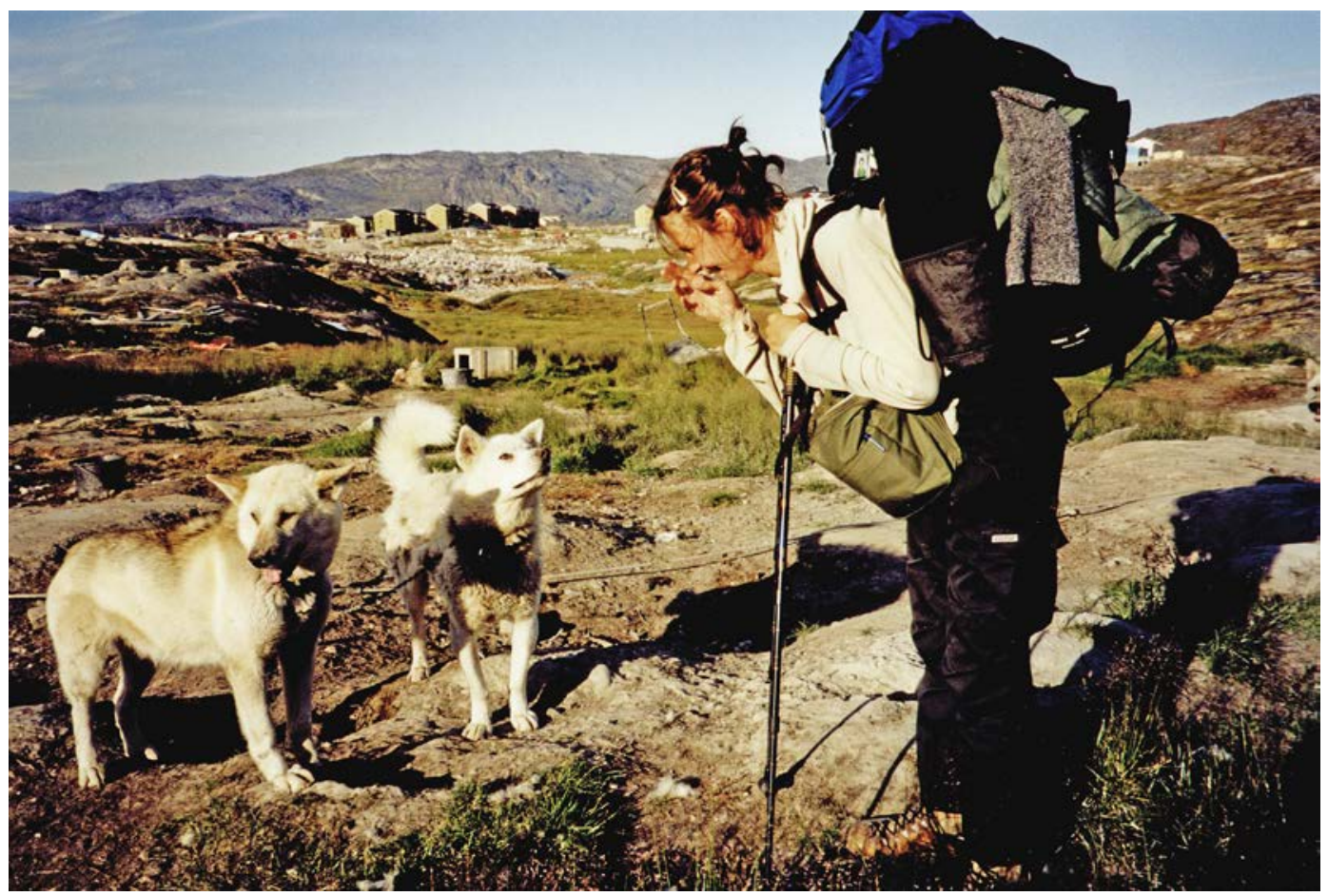

Image 2. R. van Klaveren, 2001, Bonjour Monsieur Courbet

\section{THE TIME FACTOR}

The building of a good relationship between an artist and a community, necessary for the aimed feeling of together-ness, continues in getting to know each other. Time plays a major role in this process and can even turn indifference into true interest. Community artist Ida van der Lee remembers her first meeting with the Dutch Vissershop community as being chaotic and loud. They had just lost a twenty year's battle to sustain their beloved neighbourhood that unfortunately was sinking in the unstable soil, and they therefore appeared not to be interested in the interference of an artist at all. Also the housing corporation, an important partner within the project, was not happy with the artist's proposal to save one of the houses from destruction by placing a huge cage around it, and let it turn into a ruin (Van der Lee, 2006). These two encounters are typical for an unfortunate start of the relationship between the artist and the community s/he wishes to work with. Arriving artists should never expect to be applauded by their presence or by their previous work, because that is simply not so often wished for nor understood. And the ideas they have in mind for the community should be handled with even more care, no matter how brilliant they might be. 'You shouldn't retain your own artistic concept too strong," advices the choreographer of the community art play 'Hand in Hand', "but you need a concept to grow enthusiasm" (Van Veenen, 2009). Acknowledging the position of the artist as being the outsider or the 'them' in the eyes of the community members, the one who supposes to know what's good for the community, makes some precaution understandable. If the situation is already a bit touchy, it becomes comprehensible to find the artist arrogant, or even carping.

Van der Lee handled her bumpy start rather well. Although she admits it made her moody, she handled the situation with a strong strategy: letting it be. In combination with the even more powerful factor of time, she eventually became their artist (Van der Lee, 2006). 
Spending plenty of time with the people, in their environment, sharing their concerns, their stories and their joy, is probably the most valuable method to become involved. Time can turn outsiders into insiders.

\section{THE HUMAN FACTOR}

Just as important for a good relationship are the characteristics and the background of the artist. Community art is all about being human. The human inside the artist, meaning his or her experiences, compassion, interest, impressions, emotions, social skills, and personal view upon things, strongly affects the success of this relationship. It goes beyond the size of the ego and is not to be trained in greeting exercises. There are not many other fields of art that are so influenced by the human factor, but in social sciences we can find some examples. Ethics are often mentioned as useful tools.

In ethnographic fieldwork, the importance of spending time and being human is well understood and ethics are often topic of discussion. Clifford Geertz, while basing his famous ethnographic theory of Thick description, explained how long-term, highly participative field study can give "the sort of sensible actuality that makes is possible to think not only realistically and concretely about them, but, what is more important, creatively and imaginatively with them" (Geertz, 1973). In order to enable this kind of participation, an anthropologist needs to build relationships with the community s/he studies to overcome the level of tourism and to collect data instead of souvenirs. (Lippard, 2010) During this process the human inside the anthropologist is just as influential as the one within the community artist.

As described before, anthropology is still reinventing itself after its colonial context. The word 'them' in Geertz's quote illustrates this very well. Acquiring ethical skills is inevitable in dealing with the persistent us-and-them dichotomy, and is part of an anthropologist's training. Community artists lacking these skills can therefore learn from anthropology. "It finally comes down to who exploits whom for what and why," summarized Lucy Lippard, who requires both artists and anthropologist to explain in depth why they are working in communities at all (Lippard, 2010). This elementary question is understandable to most of us when it concerns indigenous communities, but is just as necessary in working with any other group of individuals. Insider or outsider, us or them, the true reason behind the wish to interfere always needs to be known from both directions. This transparency and ethical approach are fundamental needs to start a true symbiotic collaboration.

\section{CREATING SPACES}

In order to create togetherness, a shared moment for this feeling to take place is inevitable. In his widely referred 'Relational Aesthetics', Nicolas Bourriaud described the notion of relational arts as a linking element and a principle of dynamic agglutination, "... a set of artistic practices which take as their theoretical and practical point of departure the whole of human relations and their social context, rather than an independent and private space" (Bourriaud, 2002). The encounters

produced by relational art create collectiveness. Art can be an en-counter, but it can also be a space. The social power of art lies in its possibility to create an expressive space in which the rules and regulations of social reality are reshaped, state both Bourriaud and Rancière 
(Trienekens \& Postma, 2010). In these expressive spaces, participants can creatively and imaginatively share thoughts and experiences, as was also aimed by Geertz in his quote given earlier. This is the space where the artistic participatory practices gets initiated or take place. In case of the earlier mentioned project by Ida van der Lee, a physical treasure chamber made from demolition wood from the old houses functioned as an inviting space for writing and donating memories related to the neighbourhood. In order to stimulate the imagination and the creativity, the look, feel, and other characteristics of such expressive spaces need to be given at least as much attention as the relationship. Again, time is a crucial factor. Why should participants spend time contributing if the artist hardly spent time on the look, feel and functionality of the expressive space?

The way community artists and other artists who initiate participatory practices, shape their expressive space can differ as greatly as the artists themselves. These spaces can merge with physical places or can exist in virtual environments only, or do both. In my own art practice I often created online story spaces. In the Braintec project, for example, people were invited to engage in a science fiction story by writing diaries about their virtual experiences as test subjects for a medical research company. Not only the company's website, but also a second site with virtual diaries was created as the expressive space of this project. To infiltrate physical reality, the story space was expended with company ballpoints, leaflets, flags and other promotional material used during presentations and exhibitions.

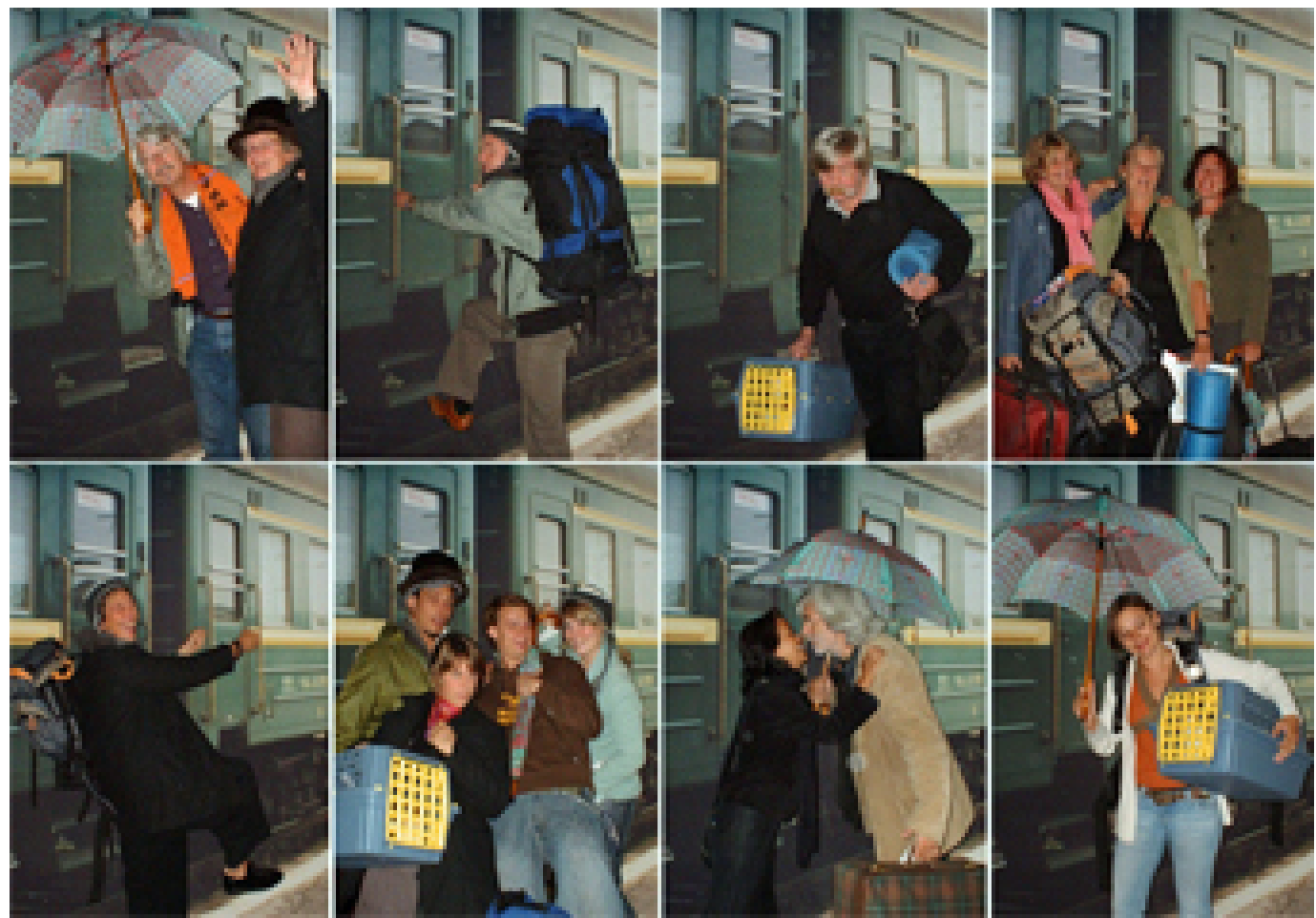

Image 3. Expressive space, De Grote Treinreis, 2005.

A slightly similar story space was created for 'De Grote Treinreis' (The Great Train Journey), where people could make self-portraits in front of a life sized picture of the Trans-Siberian Express in the museum and write travel logs about their virtual journey online. Both examples are autonomous projects, for which communities of participants originated during the process. And in both projects it was the carefully and conscientiously shaped story space that brought the people together and motivated them to keep contributing. 
If the expressive spaces of such art projects give social meaning, as stated above by Bourriaud and Rancière, where can we find the artistic meaning? If the artistry in participatory practices is to be found in a specific space created for a specific social meeting, are the aesthetics automatically there as well?

Aesthetics are often topic of debate in community art, where the location of aesthetic value can be just as flexible and diverse as the projects themselves. The aesthetics can for example be found in the encounter, in the expressive space, in the end result or in the experience of the participants. Even after many debates, this aspect of community art is still difficult to define. As a response, people who feel the need to defend this art field usually point to all kinds of surpluses. "The surplus of the artistic exists in the freedom created by the artistry", wrote Marie van Looveren about community art. "The artistry does not problematize, the artistry does not obligate, the artistry only creates a space in which everything is possible and notbing is needed" (Van Looveren, 2010).

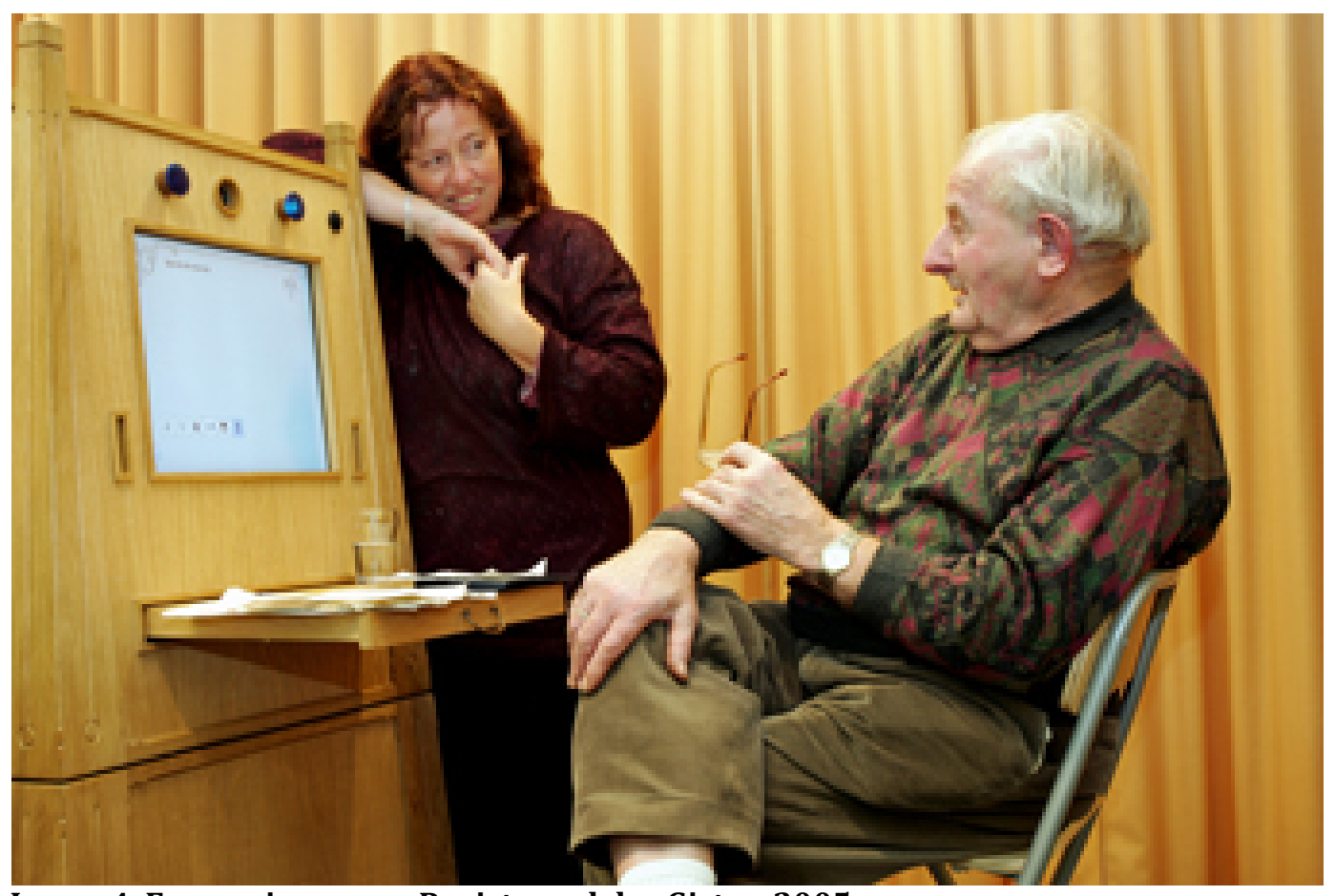

Image 4. Expressive space, Register v.d.d.v. Gister, 2005.

When one of the surpluses of the artistry in participatory practices is to create freedom, the experience of freedom might be considered a meaningful tool towards a temporary feeling of togetherness. On the other hand, too much freedom is in my experience paralyzing. In a situation where everything is possible and nothing is needed, it is hard to decide what to do. This is what I experienced during 'Register van de Dag van Gister' (Register of Yesterdays' Day), a project I worked for with Waag Society, Amsterdam. With a piece of furniture as a materialization form of expressive space, designed to collect memories from elderly people, I guided the participation of more than 40 people during the pilot stage. People were free to contribute whatever memory they wanted, about whatever topic. Only when I narrowed their options down by suggestions, they could handle this amount of freedom. After working on this project, I therefore always try to mark out expressive spaces with guiding rules, regulations or a topic. For storytelling platforms, the integration of a clear topic or a clear goal usually works best. 


\section{SHARED INTEREST}

As part of my PhD I am currently working on an online platform called FOOD RELATED, where Arctic people can exchange thoughts, anecdotes, experiences and knowledge in relation to food. My decision to choose this region as working location is based upon my personal interest and my personal wish to do a project that might support these people. The topic itself, food and food culture, is also selected with care. Food can literary bring people together (it breaks the ice and is in itself topic for sharing), food is directly connected to identity (you are what you eat), and food can restore the physical connection in virtual contact (a bodily balance). If the social and cultural experiences of food among the participating peoples are shared, they might feel 'food related'.

A clear topic not only gives character to the expressive space and clarification of the artist's intention, or a lead for contributions; it can also strengthen the feeling of togetherness.

People will participate with greater enthusiasm if the project fits within their field of interest. It can even inspire those neighbours who were asked to collaborate in community projects too often already, who will not only collaborate because the artist asked them nicely. A shared interest or goal can be so powerful that it is also able to create communities among people with different world views, backgrounds or ethnic identities. And for the artist, while working with yet another neighbourhood, a topic that truly interests him or her can be art saving. A proper search for the right topic is therefore recommended above an investment in more common ground. A clear topic or a goal can be part of the expressive space or the shared practice, or both.
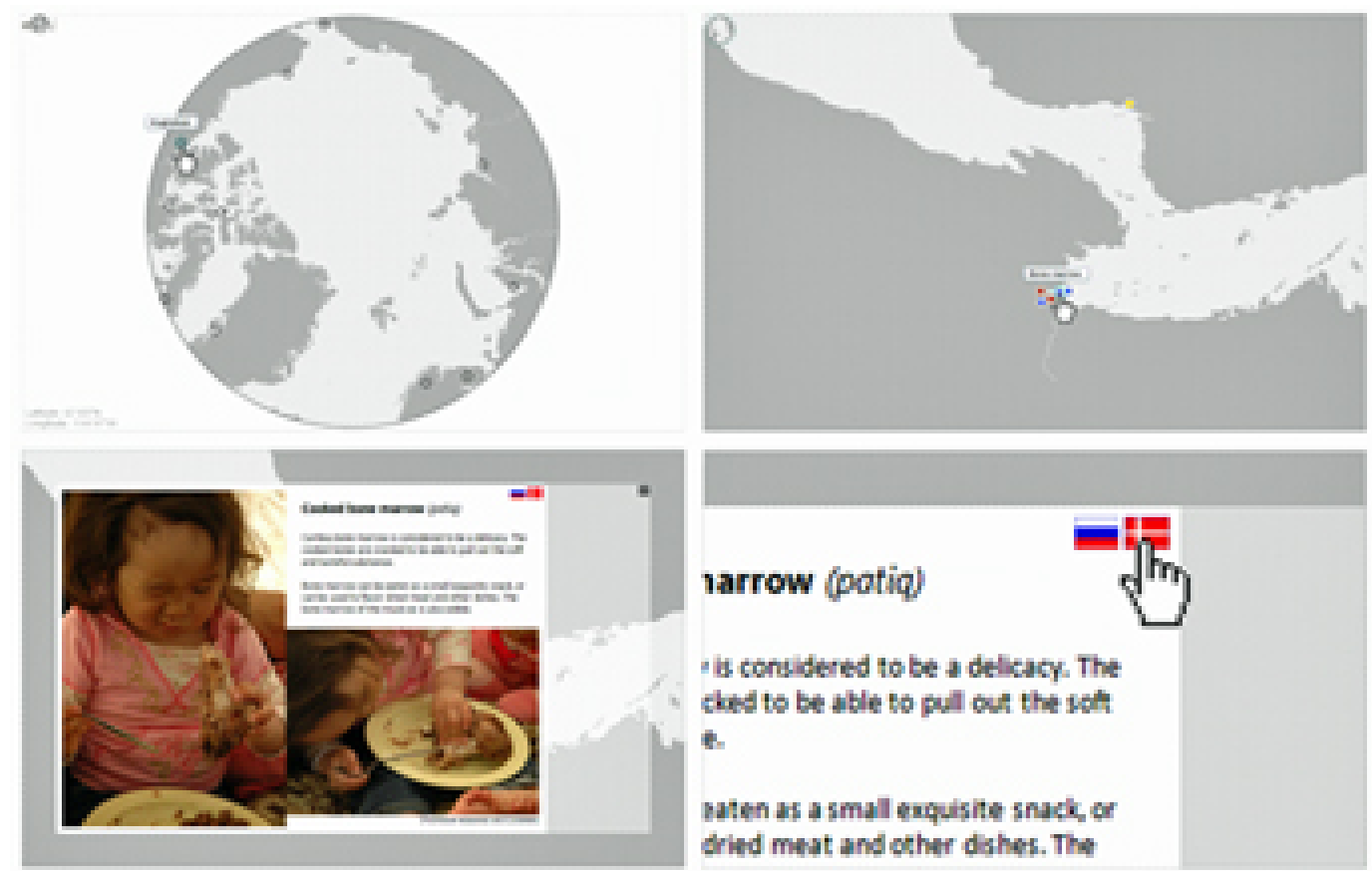

Image 5. Expressive space, FOOD RELATED, 2011. 


\section{THE ACTUAL DRIVE}

When all these conditions and aspects are integrated well, the actual participatory practices can take place. As described in the introduction, the character of these practices can differ so greatly that this is deliberately not discussed in this conference paper. Instead of mapping the wide range of things one can do and make with participants, I like to focus on certain aspects of the creative experience within these practices that can stimulate togetherness.

David Gauntlett wrote about the social meaning of creativity in 'Making is Connecting'. He explained how the Victorian Ruskin and Morris defined creativity "as a part of everyday life, and as a binding force in 'fellowship', which today we would call community" (Gauntlett, 2011). This binding force of the creative act itself seems to be just as adhesive as the dynamic agglutination Bourriaud described towards relational art. Gauntlett also connects his enthusiasm for DIY to political philosophies for a future world where all crafts and crafting is shared (Gauntlett, 2011). Although it is absolutely not my intention to ridicule his good intentions I am too sceptical or perhaps too cynical to believe that creativity can actually save the world. I believe though, that the glue for stronger connections lies indeed in the act of making things together. Creativity can be just as expressive as language but acts less intellectual. In bypassing intellectuality lies a clue to fellowship, as is also proofed in sports and gaming.

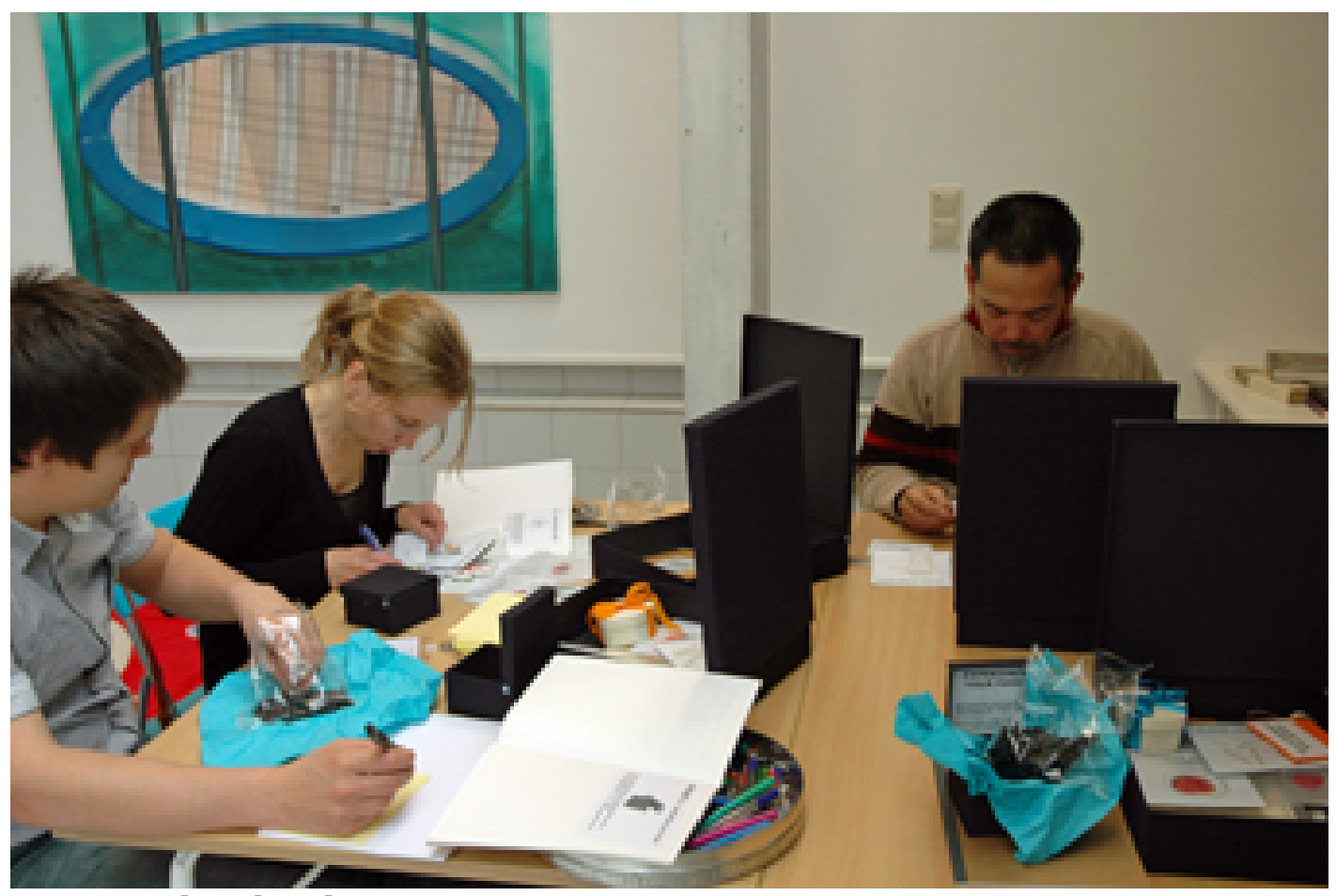

Image 6. Cultural probes, FOOD RELATED, 2011.

Creativity can encourage subjective and imaginative engagement. In order to evoke emphatic instead of intellectual responses from participants, Bill Gaver, Tony Dunne and Elena Pacenti (1999) developed cultural probes, packages of creative tasks to collect fragmentary data just like astronomic or surgical probes do. These designers struggled with similar kinds of distance between them and the community they work with as described above, which they hoped to overcome with uncertainty, play, exploration and subjective interpretation. The probes were made to give them a feel for the people they designed for and to prevent them from believing that they could look into these people's heads (Gaver et al, 2004). The creative tasks, deliberately requesting open-ended or even absurd responses, produced dialectics between the participants and the designers: "On the one hand, the returns are inescapably 
the products of people different from us, constantly confronting us with other physical, conceptual, and emotional realities. On the other hand, the returns are layered with influence, ambiguity and indirection, demanding that we see the volunteers through ourselves to make any sense" (Gaver et al, 2004). The probes create a bond between the 'us' of the designers and the 'them' of the people they designed for. Making the probes gave "a deep sense of familiarity and engagement with the people," explain the designers; "They create relation-ships with our volunteers that are a little like designing for friends" (Gaver et al, 2004).

During an artist in residence program in Kilpisjärvi in the north of Finland, I made several cultural probes packages for the FOOD RELATED project. Ten explorative tasks asked creatively about emotions, expressions and experiences of Arctic food and food culture. People in the Tromsø area in Norway have worked with them at home and during a workshop. Such creative packages are usually designed for individual use only, and need to be designed differently for collaborate use to stimulate the temporary feeling of togetherness. Yet, using and discussing the probes during a workshop gave me an important insight: attractive and conscientiously prepared elements can drastically enlarge the involvement and enthusiasm of the participants. The time and effort spent on the probes ensured them that I really cared about their experiences and their responses, while the artistry stimulated their own creativity. Whether it are probes, creative questionnaires, expressive tasks, performable actions, ludic happening or any other kind of shared activity to make or do creatively, the quality and care put into the design of these participative practices is directly linked to its appreciation. Combined with the right amount of time, favourable characteristics and background, an inviting size of ego, an attractive space for expression and a shared interest, such carefully and qualitatively designed or directed practices can create a meaningful feeling of fellowship. This feeling can bring people closer to each other and provisionally provoke the us-and-them dichotomy. Artists and other people working with com-munities can pay attention to these discussed aspects of their participatory practices to form a vehicle for temporary togetherness.

\section{REFERENCES}

Appadurai, A. Putting Hierarchy in its Place. Cultural Anthropology, 1988, 3(1): 36-49.

Doesschate Chu, P. Letters of Gustave Courbet. University of Chicago Press, Chicago, USA. 1992.

Gauntlett, D. Making is Connecting. The social meaning of creativity, from DIY and knitting to YouTube and Web 2.0. Polity Press, Cambridge, UK. 2011.

Gaver, W.W., Dunne, A., \& Pacenti, E. Cultural Probes. Interactions, 1999, (1), 21-29.

Gaver, W.W., Boucher, A., Pennington, S. \& Walker, B. Cultural Probes and the Value of Uncertainty. Interactions, 2004, 6(5), 53-56.

Geertz, G. The Interpretation of Cultures. Basic Books, New York, USA. 1973.

Lippard, L. R. Farther Afield. In: Schneider \& Wright (eds). Between Art and Anthropology. Contemporary Ethnographic Practice. Berg publishers, Oxford, UK. 2010.

Mack, G. Gustave Courbet: A Biography. Da Capo Press, Cambridge, Massachusetts, USA. 1989 (reprint 1951).

Trienekens, S. \& Postma, D.W. Verbinden door te ontwrichten. Boekman, 2010, 82:22-29.

Van der Lee, I. (eds) Sloophamer, Schatkamer. Kunst treft het Vissershop. SSP, Amsterdam, Netherlands. 2006.

Van Looveren, M. Balanceren op de breuklijn tussen sociaal en artistiek. Boekman, 2010, 82:41-45.

Van Veenen, A. Geen mooier woord dan Feyenoord. Casestudie van Community Art productie Hand in Hand. www.rotterdamswijktheater.nl, 2009. 